\title{
Fattening performance and carcass traits of Baladi and Shami-Baladi kids
}

\author{
Mohammad D. Obeidat ${ }^{1}$, Belal S. Obeidat ${ }^{1}$, Basheer Nusairat ${ }^{1}$ and Rolan Al-Shareef ${ }^{2}$ \\ 1. Department of Animal Production, Jordan University of Science and Technology, Irbid 22110, Jordan; 2. Department \\ of Nutrition and Food Technology, Jordan University of Science and Technology, Irbid 22110, Jordan. \\ Corresponding author: Mohammad D. Obeidat, e-mail: mdobeidat@just.edu.jo \\ Co-authors: BSO: bobeidat@just.edu.jo,BN: bmnusairat@just.edu.jo, RA: rmalshareef17@agr.just.edu.jo \\ Received: 18-08-2019, Accepted: 25-11-2019, Published online: 03-01-2020
}

doi: www.doi.org/10.14202/vetworld.2020.21-25 How to cite this article: Obeidat MD, Obeidat BS, Nusairat B, Al-Shareef R (2020) Fattening performance and carcass traits of Baladi and Shami-Baladi kids, Veterinary World, 13(1): 21-25.

\begin{abstract}
Background and Aim: Goat is considered very important ruminant animals that are raised in Jordan; however, the production of the local breeds is low to moderate, and thus, some genetic improvement programs could have a positive effect on the performance of the local breeds. The objective of this study was to investigate the effect of crossing Baladi (BB) goat with Shami.
\end{abstract}

Materials and Methods: A total of 30 newly weaned goat kids (15 BB and 15 Shami-Baladi [SB] kids) were evaluated for growth performance and carcass traits. The trial lasted for 77 days ( 7 days for adaptation and 70 days for data collection). Feed intake was measured on a daily basis; body weight of kids was measured at the beginning of the study and biweekly thereafter. At the end of the trial, kids were slaughtered to examine carcass traits.

Results: Dry matter intake, initial weight, final weight, and average daily gain (ADG) were not affected by kid's breed type. In addition, breed type of kids showed no significant effect on feed efficiency (feed:gain). Hot and cold carcass weight and dressing percentage were also not affected by kid's breed type. Kid breed type had no significant effect on shoulder, rack, and legs percentages. However, SB kids had a higher loin cut percentage compared to BB kids. In addition, Musculus longissimus depth was higher for SB kids.

Conclusion: Results of this study indicate that crossing SB goat breeds did not have a significant effect on either growth performance or carcass traits. Further studies using reciprocal cross may reveal different results.

Keywords: crossbred, goat, Shami.

\section{Introduction}

Goats can adapt and be productive in different types of agro-climatic zone and they also have the potential to satisfy the protein requirement of a growing human population [1]. Moreover, due to some health considerations and consumer preferences, the demand for goat meat has increased during the past several years. Goat meat had lower levels of saturated fatty acids and cholesterol, and higher levels of unsaturated fatty acids compared to lamb meat [2]. In addition, Sen et al. [3] reported that goat yielded leaner carcasses when compared to sheep. However, meat production of local goat breeds is inadequate to meet the high demand. The average mature weight of local goat breeds ranges from $32 \mathrm{~kg}$ in Dhaiwi to 40 and $46 \mathrm{~kg}$ in Desert and Mountain goat, respectively [4]. As a result, genetic improvement programs were initiated to improve the productivity of local goats. Growth parameters such as body weight (BW) and average

Copyright: Obeidat, et al. Open Access. This article is distributed under the terms of the Creative Commons Attribution 4.0 International License (http://creativecommons.org/licenses/ by/4.0/), which permits unrestricted use, distribution, and reproduction in any medium, provided you give appropriate credit to the original author(s) and the source, provide a link to the Creative Commons license, and indicate if changes were made. The Creative Commons Public Domain Dedication waiver (http:// creativecommons.org/publicdomain/zero/1.0/) applies to the data made available in this article, unless otherwise stated. daily gain (ADG) are important traits for measuring the effectiveness of selection programs. Selection is mainly based on BW between 6 and 12 months of age, with increasing BW considered an important goal [5]. However, crossbreeding is still considered the fastest way to improve the productivity of local breeds.

Some exotic breeds with noticeable meat and milk production have been imported to Jordan and raised as pure breeds or crossed with local goats. During the past decade, the most famous exotic breed that has been widely used in Jordan is Shami goat. Damascus (Shami) goat originated from Syria, Cyprus, Turkey, and other Mediterranean countries. The breed is considered to be the most predominant and important dual-purpose breed in the Middle East countries under semi-intensive or intensive production systems [6]. The significance of the current study is that it evaluates the performance of the Damascus crossbred kids which have been widely raised by producers.

The present study aimed to compare the growth and carcass traits of Baladi (BB) and Shami-Baladi (SB) crossbred kids.

\section{Materials and Methods \\ Ethical approval \\ Procedures used in the current study were approved by Jordan University of Science and}


Technology (JUST) Institutional Animal Care and Use Committee, approval number 15/3/3/490.

\section{Animals}

The study was conducted in the Northern part of Jordan at the Agricultural Research and Training Unit at JUST. A total of 30 single born goat male kids were weaned at 75 days of age and divided into two groups according to their breed type (15 BB and 15 SB kids). Data collection started after 7-day adaptation [7] of kids to the diet and experimental area. All kids were fed the same diet and water ad libitum for 70 days. At the beginning of the trial, fasting BW of kids was taken in the morning. Live BW through the trial period was recorded on biweekly intervals, and feed intake was measured on a daily basis.

\section{Slaughter procedure and carcass traits}

At the end of the feeding period of the trial, kids from each genetic group were slaughtered after fasting $12 \mathrm{~h}$ and final live BW was recorded. Kids were slaughtered by cutting the arteries and the jugular vein in the neck region and left to bleed for a few minutes. All non-carcass components such as heart, lungs, kidneys, spleen, and gastrointestinal tract were also weighed. Hot carcass weight was recorded after washing the carcass with freshwater. Carcasses were kept in the chiller for $24 \mathrm{~h}$ at $4^{\circ} \mathrm{C}$ and then cold carcass weights were recorded. Each carcass was cut into four parts (leg, shoulder, loin, and rack) following the procedure described by Abdullah et al. [8]. Each cut was weighed and then tissue depth (GR), rib fat depth (J), leg fat depth (L3), shoulder fat depth (S2), area of Musculus longissimus (LMA), eye muscle width (A), eye muscle depth (B), and fat depth (C) were recorded. The right leg cut was then sealed into plastic bags and frozen at $-20^{\circ} \mathrm{C}$ until dissected.

Before dissection, legs were thawed in cooler at $4^{\circ} \mathrm{C}$ in plastic bags. Leg was dissected and subcutaneous fat, intermuscular fat, muscle, bone, and scrap were separated and weighed. Meat quality parameters $(\mathrm{pH}$, color [CIE $1, \mathrm{a}, \mathrm{b}$ coordinates], cooking loss [CL], water holding capacity [WHC], and shear force [SF] values) were measured following the procedure described by Obeidat et al. [7].

\section{Statistical analysis}

Data were analyzed using PROC mixed procedures of SAS (SAS Inst. Inc., Cary, NC). Kids were divided into two groups according to their breed type (BB and SB). Kid initial and final BW, ADG was analyzed using mixed linear models. Fixed effect investigated included kid breed type. Kid id was modeled as random effect.

$$
Y_{i j k}=\mu+G_{i}+\varepsilon_{i j}
$$

Where:

$Y_{i j}$ is the dependent variable

$\mu$ is the overall mean

$G_{i}$ is the breed type effect, where $i=\mathrm{BB}$ or SB

$\varepsilon_{i j}$ is the random error
Carcass traits and meat quality were analyzed using a general linear model of SAS (SAS Inst. Inc., Cary, NC). Kid breed type was treated as the main effect for these traits.

$$
Y_{i j}=\mu+G_{i}+\varepsilon_{i j}
$$

Where:

$Y_{i j}$ is the dependent variable

$\mu$ is the overall mean

$G_{i}$ is the breed type effect, where $i=\mathrm{BB}$ or SB

$\varepsilon_{\mathrm{ij}}$ is the random error

For carcass cuts weights, carcass weight was included as a covariate.

$$
Y_{i j}=\mu+G_{i}+b C W+\varepsilon_{i j}
$$

Where:

$Y_{i j}$ is the dependent variable

$\mu$ is the overall mean

$G_{i}$ is the breed type effect, where $i=\mathrm{BB}$ or SB

$b C W$ linear covariate of carcass weight

$\varepsilon_{\mathrm{ij}}$ is the random error

Mean separation for all traits was performed using Tukey's-Kramer test and decision criterion was determined by the $95 \%$ confidence interval for the difference between two means.

\section{Results and Discussion}

\section{Fattening performance and feed intake}

Mean differences for feed intake, birth, initial, and final $\mathrm{BW}$, feed-to-gain ratio, and $\mathrm{ADG}$ were small between BB and SB crossbred kids (Table-1). Similarly, no differences in growth parameters between the Anglo-Nubian pure breed and crossbreed Anglo-Nubian. In addition, there were no significant differences between Anglo-Nubian crossbreed, pure Anglo-Nubian, and crossbreed Boer [9]. On the contrary, Offoumon et al. showed that the ADG of crossbreds kids presented was better than purebreds [10]. Growth rate of goats is greatly influenced by the sire and dam and mature size, in general, progeny of large breeds grows faster than the progeny of small breeds [11]. Since BB breed has smaller mature body size compared to Shami goat, this could be responsible for reducing the ADG of the crossbred kids. Table-1 shows hot and cold carcass weights and dressing percentage $(\mathrm{DP} \%)$ traits, results presenting small differences between the two genetic groups. These results are in agreement with Nayga et al. [9], the authors stated that both hot and cold carcass weights and $\mathrm{DP} \%$ did not differ between pure and crossbreed Boer and between pure and cross Anglo-Nubian. However, hot and cold carcass weights and DP\% were higher $(p<0.01)$ in Saanen $\times$ Hair goat cross than in Alpine $\times$ Hair goat and pure Hair goat [12].

\section{Carcass traits}

Small differences for shoulders, racks, legs, and total offal weights and percentages among the genetic 
Table-1: Means, SE, and 95\% CI for the difference between the means for growth performance BB and SB kids.

\begin{tabular}{|c|c|c|c|c|c|c|}
\hline \multirow[t]{3}{*}{ Trait } & \multicolumn{2}{|c|}{ Breed type $^{1}$} & \multirow[t]{3}{*}{ SE } & \multirow{3}{*}{$\begin{array}{c}\text { Mean } \\
\text { difference }\end{array}$} & \multirow{3}{*}{$\begin{array}{l}95 \% \mathrm{CI} \text { for the difference } \\
\text { between the two means }\end{array}$} & \multirow[t]{3}{*}{ p-value } \\
\hline & BB & SB & & & & \\
\hline & Mean & Mean & & & & \\
\hline Feed intake $(\mathrm{kg} / \mathrm{d})$ & 1.22 & 1.17 & 0.04 & 0.05 & $-0.02-0.02$ & 0.46 \\
\hline Birth weight $(\mathrm{kg})$ & 3.51 & 3.65 & 0.08 & -0.14 & $-0.31-1.2$ & 0.25 \\
\hline Initial weight $(\mathrm{kg})$ & 18.89 & 18.25 & 0.33 & 0.64 & $-0.33-1.61$ & 0.18 \\
\hline Final weight $(\mathrm{kg})$ & 29.18 & 29.97 & 0.52 & -0.78 & $-2.4-0.8$ & 0.31 \\
\hline ADG $(g)$ & 155 & 156 & 8.9 & -1.0 & $-0.03-0.03$ & 0.94 \\
\hline Feed-to-gain ratio & 8.20 & 7.86 & 0.31 & 0.34 & $-0.6-1.3$ & 0.44 \\
\hline Hot carcass weight $(\mathrm{kg})$ & 13.7 & 14.1 & 0.27 & -0.38 & $-1.2-0.44$ & 0.34 \\
\hline Cold carcass weight $(\mathrm{kg})$ & 13.21 & 13.34 & 0.23 & -0.13 & $-0.8-0.6$ & 0.69 \\
\hline DP\% & 44.72 & 45.24 & 0.90 & -0.52 & $-3.2-2.1$ & 0.68 \\
\hline
\end{tabular}

${ }^{1} \mathrm{BB}=$ Baladi, $\mathrm{SB}=$ Shami-Baladi, $\mathrm{CI}=$ Confidence interval, $\mathrm{ADG}=$ Average daily gain, $\mathrm{SE}=$ Standard error, $\mathrm{DP}=\mathrm{Dressing}$ percentage

Table-2: Means, SE, and 95\% CI for the difference between the means for carcass cut weight and percentage in BB and SB kids.

\begin{tabular}{|c|c|c|c|c|c|c|}
\hline \multirow[t]{3}{*}{ Trait } & \multicolumn{2}{|c|}{ Breed type $^{1}$} & \multirow[t]{3}{*}{ SE } & \multirow{3}{*}{$\begin{array}{l}\text { Mean } \\
\text { difference }\end{array}$} & \multirow{3}{*}{$\begin{array}{l}95 \% \mathrm{CI} \text { for the difference } \\
\text { between the two means }\end{array}$} & \multirow[t]{3}{*}{ p-value } \\
\hline & BB & SB & & & & \\
\hline & Mean & Mean & & & & \\
\hline Shoulders weight $(\mathrm{kg})$ & 6.12 & 6.16 & 0.12 & -0.04 & $-0.37-0.26$ & 0.73 \\
\hline Racks weight $(\mathrm{kg})$ & 1.31 & 1.34 & 0.02 & -0.03 & $-0.08-0.024$ & 0.27 \\
\hline Loin weight $(\mathrm{g})$ & 909 & 1011 & 36.0 & -102 & $-0.21-0.005$ & 0.06 \\
\hline Legs weight $(\mathrm{kg})$ & 4.4 & 4.3 & 0.09 & 0.1 & $-0.17-0.34$ & 0.48 \\
\hline Total offal weight $(\mathrm{kg})$ & 1.76 & 1.77 & 0.065 & -0.01 & $-0.2-0.188$ & 0.95 \\
\hline Shoulders (\%) & 46.0 & 46.4 & 0.82 & -0.4 & $-2.84-2.02$ & 0.72 \\
\hline Racks (\%) & 9.8 & 10.1 & 0.13 & -0.3 & $-0.61-0.16$ & 0.23 \\
\hline Loin (\%) & $6.9^{\mathrm{b}}$ & $7.6^{\mathrm{a}}$ & 0.26 & -0.7 & $-1.5--0.02$ & 0.045 \\
\hline Legs (\%) & 33.26 & 32.55 & 0.64 & 0.71 & $-1.2-2.6$ & 0.44 \\
\hline Total offal (\%) & 13.3 & 13.4 & 0.49 & -0.1 & $-1.55-1.4$ & 0.92 \\
\hline
\end{tabular}

${ }^{1} \mathrm{BB}=$ Baladi, $\mathrm{SB}=$ Shami-Baladi, $\mathrm{SE}=$ Standard error, $\mathrm{CI}=$ Confidence interval. a, bMeans with different superscripts with the same row differ $(p<0.05)$

groups were found (Table-2). Gökdal [12] also presented similar results to this study as the genotypes Alpine-Hair and Saanen-Hair males do not have any significant differences in their parts as well. In an another study, no differences were found in shoulders between Boer-Spanish when compared to SpanishAngora and pure Spanish [13]. On the other hand, there were differences observed between pure Spanish and Spanish-Angora on the leg cut while there were no differences between crossbred Boer when compared to pure Spanish. Conversely, pure Spanish differs significantly when compared to crossbred SpanishAngora [13]. Similar to the current study, no differences among the carcass offal weight by-products among Honamli, Hair, and Honamli-Hair genotypes [14]. On the contrary, edible slaughter by-products were significantly higher for the Damascus breed than other crossbred kids. The authors related that to higher live BW for Damascus breed compared with other genetic groups [15]. In the present study, absolute mean differences for loin percentage was $(0.78)$ with SB kids having higher values for this trait compared to $\mathrm{BB}$ kids. Similar to these results, Anothaisinthawee et al. [16] found significant differences in the loin weights between native (Southern Thai), two-way cross (Southern Thai $\times$ Anglo-Nubian), and three-way cross
(Boer $\times$ Anglo-Nubian $\times$ Native). On the contrary, there were no differences between pure Honamli and pure Hair when compared by Honamli-Hair kids in relation to their loin cut weight [15]. Since carcass traits are moderate to highly heritable, the advantage of the SB breed type for loin cut percentage could be attributed to breed complementarity.

The depth of subcutaneous fat over the Musculus obliquus externus abdominis (J), the depth of tissue over the surface of rib at point $110 \mathrm{~mm}$ from the midline and area of $M$. longissimus (GR), the depth of subcutaneous fat over the Musculus latissimus dorsi at a point at the right angles to the midline (S2), and fat thickness over the ventral edge of Musculus gluteus medius (L3) are reported in Table-3. No differences in composition between the two genetic groups were detected. In agreement with this study, no significant differences in fat thickness were found between BoerSpanish when compared to Spanish-Angora and pure Angora [13]. In addition, this study showed that the $M$. longissimus measurements did not differ in either depth (B) or width (A) in the between the two breed types. However, the Longissimus muscle area $\left(\mathrm{cm}^{2}\right)$ between pure Spanish and crossbred Spanish (Spanish $\times$ Boer, Spanish $\times$ Angora $)$ did not differ $(\mathrm{p}>0.05)$. Conversely, there were some differences between 
Table-3: Means, SE, and 95\% CI for the difference between the means for fat thickness and M. longissimus measurements of BB and SB kids.

\begin{tabular}{|c|c|c|c|c|c|c|}
\hline \multirow[t]{3}{*}{ Trait } & \multicolumn{2}{|c|}{ Breed type $^{1}$} & \multirow[t]{3}{*}{ SE } & \multirow{3}{*}{$\begin{array}{c}\text { Mean } \\
\text { difference }\end{array}$} & \multirow{3}{*}{$\begin{array}{l}95 \% \mathrm{CI} \text { for the difference } \\
\text { between the two means }\end{array}$} & \multirow[t]{3}{*}{ p-value } \\
\hline & BB & SB & & & & \\
\hline & Mean & Mean & & & & \\
\hline$\overline{\mathrm{L} 3}$ & 1.15 & 1.15 & 0.093 & 0 & $-0.27-0.27$ & 0.95 \\
\hline $\mathrm{S} 2$ & 1.00 & 1.05 & 0.04 & -0.05 & $-0.16-0.06$ & 0.331 \\
\hline J & 1.35 & 1.40 & 0.13 & -0.05 & $-0.43-0.33$ & 0.785 \\
\hline $\mathrm{GR}$ & 8.88 & 8.61 & 0.27 & 0.27 & $-0.53-1.08$ & 0.489 \\
\hline$A$ & 49.35 & 48.95 & 0.75 & 0.40 & $-1.8-2.6$ & 0.709 \\
\hline B & 27.8 & 20.2 & 6.0 & 7.6 & $-10.19-25.5$ & 0.379 \\
\hline $\mathrm{C}$ & 1.05 & 1.00 & 0.04 & 0.05 & $-0.06-0.16$ & 0.331 \\
\hline
\end{tabular}

${ }^{1} \mathrm{~L} 3=$ Fat thickness over the ventral edge of Musculus gluteus medius, $\mathrm{S} 2=$ The depth of subcutaneous fat over the Musculus latissius dorsi at appoint at right angles to the midline, $\mathrm{J}=$ The depth of subcutaneous fat over the Musculus obliquus externus abdominis, $\mathrm{GR}=$ The depth of tissue over the surface of rib at point $110 \mathrm{~mm}$ from the midline, $\mathrm{A}=$ Musculus longissimus width, $\mathrm{B}=$ Musculus longissimus depth=Baladi, SB=Shami-Baladi, SE=Standard error, $\mathrm{CI}=$ Confidence interval. ${ }^{a, b}$ Means with different superscripts with the same row differ $(p<0.05)$

Table-4: Means, SE, and 95\% CI for the difference between the means for meat quality traits of BB and SB kids.

\begin{tabular}{|c|c|c|c|c|c|c|}
\hline \multirow[t]{3}{*}{ Trait } & \multicolumn{2}{|c|}{ Breed type $^{1}$} & \multirow[t]{3}{*}{ SE } & \multirow{3}{*}{$\begin{array}{c}\text { Mean } \\
\text { difference }\end{array}$} & \multirow{3}{*}{$\begin{array}{l}95 \% \mathrm{CI} \text { for the difference } \\
\text { between the two means }\end{array}$} & \multirow[t]{3}{*}{ p-value } \\
\hline & BB & SB & & & & \\
\hline & Mean & Mean & & & & \\
\hline$\overline{\mathrm{CL}}$ & 38.15 & 38.21 & 0.97 & -0.055 & $-2.96-2.84$ & 0.968 \\
\hline WHC & 23.89 & 22.07 & 0.95 & 1.82 & $-1.02-4.7$ & 0.195 \\
\hline SF & 9.26 & 8.82 & 0.64 & 0.44 & $-1.47-2.36$ & 0.632 \\
\hline $\mathrm{pH}$ & 5.76 & 5.77 & 0.018 & -0.01 & $-0.06-0.05$ & 0.816 \\
\hline i & 35.78 & 37.56 & 1.63 & -1.78 & $-6.66-3.10$ & 0.452 \\
\hline a & 2.52 & 2.25 & 0.22 & 0.27 & $-0.37-0.91$ & 0.387 \\
\hline$b$ & $16.74^{\mathrm{b}}$ & $19.00^{\mathrm{a}}$ & 0.55 & -2.26 & $-3.86--0.66$ & 0.008 \\
\hline
\end{tabular}

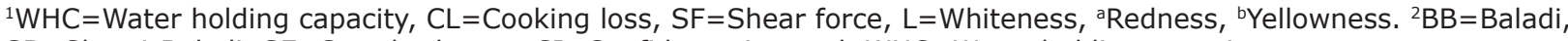
$\mathrm{SB}=$ Shami-Baladi, $\mathrm{SE}=$ Standard error, $\mathrm{CI}=$ Confidence interval, WHC=Water holding capacity

Table-5: Means, SD, and 95\% CI for the difference between the means for leg cut of BB and SB kids.

\begin{tabular}{|c|c|c|c|c|c|c|}
\hline \multirow[t]{3}{*}{ Trait } & \multicolumn{2}{|c|}{ Breed type $^{1}$} & \multirow[t]{3}{*}{ SE } & \multirow{3}{*}{$\begin{array}{c}\text { Mean } \\
\text { difference }\end{array}$} & \multirow{3}{*}{$\begin{array}{l}95 \% \mathrm{CI} \text { for the difference } \\
\text { between the two means }\end{array}$} & \multirow[t]{3}{*}{ p-value } \\
\hline & BB & SB & & & & \\
\hline & Mean & Mean & & & & \\
\hline Leg weight (kg) & 2.19 & 2.21 & 0.2 & -0.02 & $-0.071-0.053$ & 0.772 \\
\hline Total muscle $(\mathrm{kg})$ & 1.27 & 1.07 & 0.103 & 0.2 & $-0.108-0.507$ & 0.189 \\
\hline Total bone $(\mathrm{g})$ & 564.9 & 590.1 & 12.8 & -25.2 & $-63.46-13.04$ & 0.182 \\
\hline Subcutaneous fat (g) & 126.6 & 149.4 & 14.16 & -22.8 & $-65.1-19.5$ & 0.271 \\
\hline Intramuscular fat (g) & 60.9 & 57.1 & 5.4 & 3.8 & $-12.25-19.87$ & 0.623 \\
\hline
\end{tabular}

${ }^{1} \mathrm{BB}=$ Baladi, SB=Shami-Baladi, $\mathrm{SD}=$ Standard deviation, $\mathrm{CI}=$ Confidence interval, $\mathrm{SE}=$ Standard error

pure Angora and Spanish-Angora. This shows that the breed that improved the characteristics of the Longissimus muscle area was the Angora breed [13].

Meat quality traits are presented in Table- 4 . This study concluded that the mean differences for traits were small when comparing between the two breed types; however, high mean differences (2.26) for yellowness (b) were found; SB had higher values than BB kids. In addition, Lopes et al. [17] reported that there were no differences between both crossbred and pure kids in SF and CL. On the other hand, crossbred French Alpine-Boer produced higher meat quality (WHC, $\mathrm{pH}$, and color) in comparison with their pure genotypes, respectively [18]. Moreover, significant differences were found in the lightness (a) and redness (a) but no differences in the yellowness (b) between pure Bravia and Serrana and their crosses [19].
In the present study, as presented in Table-5, none of the results of the leg cut weights indicate differences in crossbred kids. Akbaş and Saatc1 [14] showed similar results stating that the long leg weight (g) did not differ among Honamli, Hair, and Honamli-Hair breeds [14]. Carcass and leg compactness index depends on the weight at which the kids were slaughtered rather than on the breed, genotype, or production systems [20]. In agreement with the previous study, there were no differences in the lean percentage in the legs of pure Spanish when compared with crossbred Spanish, while there were significant differences among these three genotypes in the bone and fat percentage of the leg [13].

\section{Conclusion}

Crossing Shami goat with BB did not have a significant value on either growth performance or carcass 
traits. The only improvement in this mating system was for the percentage and depth of the Longissimus muscle. Future studies using the reciprocal cross and under different environmental conditions may reveal different findings.

\section{Authors' Contributions}

MDO: Designing, supervising, and writing the manuscript. BSO: Helped in statistical analysis and manuscript writing. BN: Helped in technical writing. RA: Drafted the manuscript. All authors read and approved the final manuscript.

\section{Acknowledgments}

The authors wish to thank the Deanship of Scientific Research at Jordan University of Science and Technology for the financial support of this project (79/2015). The authors would like to thank Dr. David Riley for his help and suggestions in statistical analysis.

\section{Competing Interests}

The authors declare that they have no competing interests.

\section{Publisher's Note}

Veterinary World remains neutral with regard to jurisdictional claims in published institutional affiliation.

\section{References}

1. Food and Agriculture Organisation of the United Nations. (2015) Documents. Food and Agriculture Organisation of the United Nations, New York.

2. Ivanović, S., Pavlović, I. and Pisinov, B. (2016) The quality of goat meat and it's impact on human health. Biotechnol. Anim, Husbandry, 32(2): 111-122.

3. Sen, A.R., Santra, A. and Karim, A.S. (2004) Carcass yield, composition and meat quality attributes of sheep and goat under semiarid conditions. Meat Sci., 66(4): 757-763.

4. Al-Rousan, L. (2009) Goat production in Jordan. Proceedings of the $24^{\text {th }}$ Annual Goat Field Day, Langston University.

5. Gowane, G.R., Chopra, A., Prakash, V. and Arora, A.L. (2011) Estimates of (co)variance components and genetic parameters for growth traits in Sirohi goat. Trop. Anim. Health Prod., 43(1): 189-198.

6. Brown-Crowder, I.E., Hart, S.P., Cameron, M., Sahlu, T. and Goetsch, A.L. (2001) Effects of dietary tallow level on performance of alpine does in early lactation. Small Rumin. Res., 39(3): 233-241.

7. Obeidat, B.S., Mahmoud, K.Z., Maswadeh, J.A. and
Bsoul, E.Y. (2016) Effects of feeding Atriplex halimus L. on growth performance and carcass characteristics of fattening awassi lambs. Small Rumin. Res., 137(4): 65-70.

8. Abdullah, A.Y., Kridli, R.T., Shaker, M.M. and Obeidat, M.D. (2010) Investigation of growth and carcass characteristics of pure and crossbred Awassi lambs. Small Rumin. Res., 94(1-3): 167-175.

9. Nayga, J.N., Valdez, E.B., Andres, M.R., Estrada, B.B., Lopez, E.A. and Tamayo, R.B. (2015) Slaughter and carcass characterization, and sensory qualities of native, pure, and upgraded breeds of goat raised in the Philippines. Int. J. Biol. Biomol. Agric. Food Biotechnol. Eng., 9(10): $1125-1128$.

10. Offoumon, O.T., La, F., Bauima, A.B., Idrissou, Y., Assani, A.S., Assogba, B.G.C. and Alkoiret, I.T. (2018) Growth performance of Saanen, Red maradi and the crossbred Saanen versus Red maradi goats in Soudanese area of Benin. Int. Res. J. Nat. Appl. Sci., 5(5): 1-14.

11. McGregor, B.A. (1985) Growth, Development and carcass composition of goats: A review. In: Proceedings of the Goat Production and Research in the Tropics, Feb. 6-8, 1984, University of Queensland. ACIAR, Brisbane. p82-90.

12. Gökdal, O. (2013) Growth, slaughter and carcass characteristics of Alpine hair goat, Saanen hair goat and hair goat male kids fed with concentrate in addition to grazing on rangeland. Small Rumin. Res., 112(109): 35-38.

13. Oman, J.S., Waldron, D.F., Griffin, D.B. and Savell, J.W. (2000) Carcass traits and retail display-life of chops from different goat breed types. J. Anim. Sci., 78(5): 1262-1266.

14. Akbaş, A. and Saatcı, M. (2016) Growth, slaughter, and carcass characteristics of Honaml, Hair, and Honaml1 hair (F1) male goat kids bred under extensive conditions. Turk. J. Vet. Anim. Sci., 40(4): 459-467.

15. Ahtash, A.E., Biala, A.S., Magid, A.F. and Marhoun, H.M. (2010) Carcass Characteristics of the Libyan purebred Mahali goat and their crosses with Damascus and Morica Granada goats. Agric. Marine Sci., 15: 21-27.

16. Anothaisinthawee, S., Wattanachant, C., Nomura, K., Oishi, T. and Amano, T. (2012) Carcass and meat quality of three genotype populations in goat breeding for meat purposes in Thailand. J. Agric. Sci., 57(1): 63-70.

17. Lopes, L.S., Martins, S.R., Chizzotti, M.L., Busato, K.C., Oliveira, I.M., Neto, O.R.M., Paulinoc, P.V.R., Lanna, D.P.D. and Ladeira, M.M. (2014) Meat quality and fatty acid profile of Brazilian goats subjected to different nutritional treatments. Meat Sci., 97(4): 602-608.

18. Brzostowski, H., Niznikowski, R. and Tanski, Z. (2008) Quality of goat meat from purebred French Alpine kids and Boer crossbreeds. Arch. Tierz., 52(4): 381-388.

19. Santos, V., Silva, A.O., Cardoso, J., Silvestre, A., Silva, S.R. and Martins, C. (2007) Genotype and sex effects on carcass and meat quality of suckling kids protected by the PGI Cabrito de Barroso. Meat Sci., 75(4): 725-736.

20. Yakan, A., Ates, C.T., Alasahan, S., Odabasioglu, F., Unal, N. and Ozturk, O.H. (2016) Damascus kids slaughter, carcass and meat quality traits in different production systems using antioxidant supplementation. Small Rumin. Res., 136(3) 43-53. 